\title{
PMI (Public Media Institution Radio Television of Vojvodina the New Media Organization
}

\author{
MsC Sonja Kokotović \\ The coordinator in the cabinet General Director of the PMI RTV; \\ PhD student at the Faculty of Technical Sciences in Novi Sad \\ PhD Miodrag Koprivica
}

General Director of the PMI RTV;

Professor at the Faculty of Law and Business Studies, Dr Lazar Vrkatić in Novi Sad

\begin{abstract}
The basis of the effective functioning of the media along with the changes in the environment is in a constant development of management within the media, and therefore the corporate communication as a basic tool of development. Management JMU RTV broadcasting in the new (multi) media environment should establish a system of effective management of the technical, organizational, as well as innovation in the design and distribution of media content, aiming to find a balance between the needs of the market and the insatiable appetite of the media to the public, changes in technology, media legislation and general social trends. If the organization said that "the organism", then the communication is "bloodstream" of the organism. Corporate communication is a newer discipline which is used in all business segments worldwide. Top management creates, defines and improves corporate reputation through corporate communications and image management that created it. The image of a good and successful organization begins within. The level of satisfaction and motivation of our employees is a measurable and constant process that can be influenced, eg. how often and in which way to communicate with employees, how they transmit important messages and direct them towards achieving business goals.Corporate communication includes all communication and information activities among the members of the organization, it is targeted and oriented according to the success. Because the image of the organization can be understood as the reflection of its identity created corporate communication between different public - internal and external.
\end{abstract}

Keywords: corporate communications, reputation, corporate identity, image, management, organisational learning, public service, changes

\section{Introduction}

The success of an organization nowadays depends to a great extent on itself, but it is in direct conjunction with innovation, creativity and flexibility. The prerequisite for this is a good corporate communication, because it is the only way possible to understand the different wishes, requirements and needs of viewers / listeners / users of the portal and to adequately react in terms of programming, production and technology in order to meet their needs.

One of the helpful advantages and basic competences of successful people is to be able to communicate effectively and efficiently. Modern business world sets high standards which managers have to meet in order for the communication to be effective within and outside the organization. One of the manager's tasks is to accomplish organizational goals by communication and coordination of the employees' tasks (Jovanović, M., Živković, M. i Cvetkovski, T., 2003, 65-118). Understanding of theory and practice will be useful for creating better working environment as a precondition of good communication.

Aim of this paper is to show the importance of the role of corporate communication in modern and successful organizations such as Public Media Institution Radio-Television of Vojvodina, also how substantially corporate communication affects the creation of this organization's new image which can also be the source of competitive advantage of the organization 
regardless that this is Public service. This paper thoroughly deals with the area of corporate communication as an important tool which is at disposal for the management of PMI RTV1 and it serves for effective image managing and competitiveness of the organization.

The review and detailed analysis of the literature, hypotheses and research have been carried out in order to prove them, i.e. that the intensity of corporate communication has a positive effect on the PMI RTV's image, respectively, that a positive image directly affects the increase of competitiveness of PMI RTV, and thus greater viewership, listenership and citations.

Relations with the environment (internal and external) should be an important part of business policy of every organization and a resource for top management in organizations. Confidence and interest are very important for corporate communication because they represent a base for new, permanent relations between business partners or service users (viewers/listeners/portal users in this case).

\section{Corporate Communication - Term And Benefits heoretical Framework}

Understanding the role of communications for the market success of the organization, led to higher positioning of this business function in the organizational structure, thus influencing strategic decisions. At the same time, scientists are beginning to study the strategic importance of corporate communications and their role in building competitive advantages (Forman J. \& Argenti P.A., 2005.), and define them as planned obtaining of information from the environment and their exchange within the organization, as well as exchanges between the organization and various segments of the environment in which it operates. Communication is very important so that the organization could more effectively achieve its intended goals. The more functional it is, the more likely the achievement of the objective is, which is why the number of portable communication places is reduced to a minimum. Managers, by hiring quality staff, developing knowledge, innovation, create an adequate strategy of corporate communications and solutions in order to create a sustainable competitive advantage in the market.

Understanding of the role of communication for market success of the organization led to high positioning of this business function in organizational structure which therefore affects strategic decisions. At the same time, scientists, especially those who are studying public relations, are starting to study the strategic importance of corporate communication and its role in building competitive advantage (Forman, J. i Agenti, P.A., 2005, 245-264). In general, the role of corporate communication reflects, first of all, in the area of building corporate identity, corporate brand and company's reputation (Hawabhay, B.B. Abratt, R. i Peters, M., 2009, 3-20; Forman, J. i Agenti, P.A., 2005, 245-264; Flatt, S.J. i Kowalczik, S.J., 2008,13-30). The first two concepts are directly connected to the marketing theory, and the concept of reputation develops in the area of the management theory and public relations (Dowling, G., 2004, 196-205).

Corporate communications can be defined as planned obtaining of information and its exchange within an organization, as well as the exchange of information between the organization and different parts of the environment in which it operates. In the modern world, no organization can survive if it is not in constant communication with external environment which they inform about and which is being informed.

Organizations are formed and they survive with the consent and support of the public. Arthur Page's famous statement, who is a pioneer in the area of public relations, also testifies about this and says that in a democratic society every business starts with the permit of the public and it exists with its permission (Capozzi,L., 2005, 209-293). The public is consisted of individuals and institutions to which the organization is directed, and they can be divided in separate groups such as: financial public, media public, government and its institutions, civil sector, local community, employees, competition, business partners and suppliers, business buyers, consumers and service users. In modern management theory, these specific groups of public are called stakeholders2. The success of a company also depends on how it is seen by its stakeholders. Focus on development of different stakeholders' positive perception means active usage of corporate communication in order to effectively communicate the key values of the organization to the stakeholders. This approach received affirmation from numerous organizations and relevant literature as reputation management. That means that

\footnotetext{
1 PMI RTV - abbreviation for Public Media Institution Radio-Television of Vojvodina

2 Stakeholders - term for those individuals, institutions, groups, which have a certain type of stake (not necessarily financial) and benefits related to the existence of the company in the market (Freeman i McVea, 2001).
} 
management of an organization has to adjust its activities to the needs and interests of numerous interested parties, and in that process corporate communication becomes very important as a business function.

Financial operations ceased to be solely a measure of success, but in addition to financial indicators that reflected competitive advantage, today there are also so-called soft factors, where the reputation of an organization has a particularly important place (Flatt, S.J. i Kowalczik, S.J., 2008, 13-30). Good reputation is a result of successful activities in corporate communications (Burke, T., 1998., 5-10). Creation or improvement of business reputation means changes in the way of thinking and working of the organization in all of its forms on the market. The key role in that process has communication with internal and external stakeholders. By employing quality personnel, improvement of knowledge, innovations, quality and affirmation of social responsibility, an organization comes into a position to create an adequate strategy of corporate communications and solutions that will ensure the transition of corporate identity and internal determinants of corporate reputation in the desired image in order to create a sustainable competitive advantage in the market and values for stakeholders.

\section{Image - Definition}

During the mid 50s of the last century, image becomes an important factor for organizations. At the time, the campaigns dedicated to the image had a task to familiarize consumers with a particular brand/organization, and tie them to them, with the aim of creating competitive advantage. As a result of not engaging employees in the process of building identity and reputation, even the best image campaigns failed. That is why it is said that the image of a good and successful organization starts within itself. Many modern authors (Kotler,P., 1997, 292; Grey, E. i Smeltzer, L., 1985, 73-78 i Barich, H. i Kotler, P., $1991,94)$ define image in corporate sense as a manifestation of all mental images that people have about the organization. Described concept of image is based on external, because it all comes down to how a certain image is perceived by the target audience. Based on this, we can come to a conclusion that the image of an organization is directly related to its success in the market, affecting its competitiveness, achieved results and the general level of quality of its operations.

Image can be defined as a cognitive image of an organization, product, person, process or situation that an individual shapes based on previous experience, attitudes, opinions and performance that are more or less in line with the actual characteristics, while the role of communication, especially public relations, publicity and advertising is particularly significant in the formation of the image (Cornelissen, P., 2003, 217-234). Some authors state that the image of a company is in fact a network design which emerged from the interaction of many experiences, beliefs and knowledge that people have about certain company (Worchester, R., 1997, 146).

Image of an organization can easily be transformed, but if it does not invest continuous effort in maintaining the good image, a positive one can easily turn into negative. Precisely because of that, corporate communications must be constantly focused on image of the organization, which is its refection in the eyes of internal and external public. The image should be consistent, homogeneous and identical to the internal and external public.

Marketing communication is directly focused on the attempt to create a desired image and to attempt to provide a precise answer to the question about the extent to which the image is really useful for an individual or organization, where it can be applied best and which communication tools and methods can achieve positive and quality image. The way of communication of the desired image must be adapted to the target group by selecting appropriate communication channels, as well as the structure of the communication message. A good image of an organization means that its communication activities are intensive and that they are set properly and that it benefits from them (it increases competitiveness) (Balmer, J.M.T. i van Riel, C.B.M., 1997, 340-355). At the same time it is associated with numerous organization attributes such as the name, structure, diversity of products and services, tradition, ideology, and the overall quality impression communicated by each employee in the organization towards its clients/customers or target communication groups (van Riel, C.B.M., 1995).

The process of image management of an organization is a systematic approach of solving problems at the level of organization that begins with analyzing the current situation and setting goals, and ends with the process of checking and comparing the actual and the desired image, and the implementation of necessary corrections. Questions: "Does the organization properly and adequately use all the possibilities offered by the application of corporate communication?" and "How compliant is the internal image of the organization with the external image?", are always open. The image of the 
organization is the main factor that distinguishes it from the competition and its comprehensiveness and integrity is based on the uniform corporate communication activities.

The key element in creating the image of an organization is its employees. If they do not understand the objectives of creating certain image and if they do not apply them in public, there will be lack of desired results. There may be "deliberate" resistance to change, but sometimes the procedures of creating the image itself is not sufficiently clear and presented in a consistent manner. A positive result can be expected only if everyone is aware of the significance of the changes and if they adopt them as their personal and common values.

\section{Specificity Of PMI RTV}

"Public service is a nonprofit, independent radio-television organization, established in the name of the general public and financed from public funds, that meets the needs of the largest possible number of citizens, and the general public by diverse, balanced, high-quality programs, impartially and without discrimination". (Veljanovski, R., 2005, 28) "It is free from political interference and pressure from commercial forces. With secured pluralism, programming diversity, editorial independence, appropriate funding, accountability and transparency, public service can serve as the foundation of democracy". (Mendel, T., 1999, 10.11.2015.)

PMI RTV is a successor of RTV Novi Sad, which started broadcasting radio program in 1945, and television program in 1975. It was estalished on $26^{\text {th }}$ May 2006. on the basis of Article 94. of the Broadcasting Act (RS, Ministry of Information, 2006, $20^{\text {th }}$ January 2014.), and since $13^{\text {th }}$ August 2014. according to the Law on Public Media Services (RS National Assembly, 2014, 20 th August 2014.), it continues to operate under the name of Public Media Institution Radio-Television Vojvodina. The main activity of RTV ${ }^{1}$ is production, purchase, processing and broadcasting of television and radio programs, informational, cultural, educational, children, entertainment, sports and other content in 11 languages, 24 hours a day, which meet the needs of a wide audience in Vojvodina and beyond. During 2013, the Strategy of RTV was adopted which defines the vision, mission and general courses of action and development, "BI ${ }^{2} \mathrm{RTV}$ is a public service broadcaster for the territory of the Autonomous Province of Vojvodina which broadcasts all day program on two television and three radio channels as well as through the internet portal. With approximately 18,000 hours of the broadcast program content per year (out of which more than $50 \%$ is its own production), this institution is in the "golden middle" of program offers of European national public service, and in comparison with regional services it is among the top five in Europe." (RTV, 2013, 25th August 2013.).

Finantial strategies are also defined, and some of them are marketing strategy and public relationas: "Increased income from marketing activities is one of the main reasons for fundamental change in the system of preparation of the program and the business plan, which should be well-timed, complete and roll-on oriented. Public service RTV was created to meet the needs of the public and citizens and that is why the communication with the public should be paid attention to." "Networks of NGOs and civil society require adequate processing. No one will promote RTV if it does not engage itself for that cause. The battle for affectation of the public cannot be won only by quality programming content, but also by modern and constant communication. Multimedia portal is of a great significance, as well as transparency of the work. The very nature of the management of public funds obliges to that, but also the obligations summarized in international documents (European Council, EU, EBU)." (RTV, 2013, 25 th August 2013.)

Technical functioning is important for functioning and performance of the basic activities of a media service (production and distribution of content), such as PMI RTV Vojvodina. Because of the complete destruction during bombing in 1999, the functioning of the Public Service was enabled by the rest of the equipment and the temporary installation in a rented room with inadequate working conditions for a professional TV. RTV digitalized its infrastructure in the standard definition in $2009 / 10$ by its own means, and the process of transition from analogue to digital broadcasting was completed on $18^{\text {th }}$ May 2015. By digitizing existing audio and video archives a digital archive system is being prepared. Current systems are multifunctional, with a high degree of integration of the radio, television, and internet and mobile applications, which enable interactivity, reliability, cost effectiveness, modular and phased feasibility, expandability, sustainability and coherence.

\footnotetext{
1 PMI RTV - abbreviation for Public Media Institution Radio-Television of Vojvodina

$2 \mathrm{BI}$ - abbreviation for Broadcasting Institution 


\section{Research Methodology}

If a management of an organization does not understand the importance of proper, systematized and organized corporate communication, as well as the importance of its integration and application, it will not be able to fit in the modern market trends. The image of an organization itself is how it is seen by the public and it shows the level of integrated communication in an organization. Therefore, organizations need to adapt their own communication message according to the expectations of the target public, their attitudes, interests and specific knowledge.

In the very process of the research, many scientific research methods are applied. First, a detailed analysis of the available literature, primary and secondary data sources, and their synthesis methods of description, classification and comparison are conducted. Then, the established scientific findings were synthesized and two hypotheses were defined whose determination of truthfulness was the subject of the research:

Hypothesis H1: the intensity of corporate communications has a positive effect on creation of PMI RTV's image.

Hypothesis H2: positive image of PMI RTV has a positive effect on increasing competitiveness of PMI RTV.

In order for the hypothesis $\mathrm{H} 1$ to be accepted, the research needs to meet the following conditions:

multiple regression model is statistically significant at the level $p<0.05$

appropriate beta coefficient is statistically significant at the level $p<0.05$

appropriate beta coefficient is in expected direction

In order for the hypothesis $\mathrm{H} 2$ to be accepted, the research needs to meet the following conditions:

the correlation coefficient is statistically significant at the level $p<0.05$

the correlation coefficient is in expected direction

Data were gathered in the field by surveying the external public. The research included 1,012 subjects on the territory of AP of Vojvodina, out of which $49,9 \%$ were male and $50,1 \%$ were female respondents, aged between $18-60+$, of all educational backgrounds, occupations and social status, and it was conducted during September and October in 2015. Respondents for whom it was thought that they would be able to answer the survey questions were chosen as a sample, taking into consideration the complexity of the research issues. The structure of the samples is shown in Table 1.

Table 1. The structure of the samples

\begin{tabular}{|c|c|c|}
\hline Sample & 1012 & $\%$ \\
\hline \multirow{2}{*}{ Gender } & male & 49,9 \\
\hline & female & 50,1 \\
\hline \multirow{4}{*}{ Age } & $18-29$ & 18,8 \\
\hline & $30-44$ & 24,9 \\
\hline & $45-59$ & 27,6 \\
\hline & $60+$ & 28,7 \\
\hline \multirow{5}{*}{ Educational status } & $\begin{array}{l}\text { Without school, unfinished elementary school } \\
\text { and elementary school }\end{array}$ & 1,6 \\
\hline & Three or two years of high school & 10,8 \\
\hline & Four years of high school or gymnasium & 30,2 \\
\hline & College or faculty & 53,9 \\
\hline & Magister degree or doctor of science & 3,5 \\
\hline \multirow{4}{*}{ Employment status } & Employed in the public sector & 25,6 \\
\hline & Employed in social or combined sector & 16,2 \\
\hline & Employed in private sector & 23,9 \\
\hline & Unemployed (housewife) & 4,6 \\
\hline
\end{tabular}




\begin{tabular}{|l|l|l|}
\hline \multirow{5}{*}{} & Retired & 8,0 \\
\cline { 2 - 3 } & Agriculturist & 8,1 \\
\cline { 2 - 3 } & Pupil, student & 9,0 \\
\cline { 2 - 3 } & Unofficially employed (unregistered work) & 3,6 \\
\cline { 2 - 3 } & Did not give an answer & 1,0 \\
\hline \multirow{5}{*}{ wach TV programs } & In Serbian language & 84,2 \\
\cline { 2 - 3 } & In Hungarian language & 7,4 \\
\cline { 2 - 3 } & In Romanian language & 0,3 \\
\cline { 2 - 3 } & In Ruthenian language & 0,1 \\
\cline { 2 - 3 } & In Slovak language & 1,2 \\
\cline { 2 - 3 } & In Bunjevac dialect & 0,4 \\
\cline { 2 - 3 } & In Ukrainian language & 0,2 \\
\cline { 2 - 3 } & In Croatian language & 2,9 \\
\cline { 2 - 3 } & In Macedonian language & 0,1 \\
\cline { 2 - 3 } & In Romani language & 0,1 \\
\cline { 2 - 3 } & Another language & 0,5 \\
\hline \multirow{5}{*}{ Settlement type } & Urban & 59,4 \\
\cline { 2 - 3 } & Rural & 40,6 \\
\hline
\end{tabular}

By surveying the external public, attitude of respondents on the quality of the image of PMI RTV Vojvodina and on its competitiveness and intensity of application of various forms of corporate communication was researched. The instrument for this survey was a questionnaire. The studied variables were measured using measurement scales containing attitudes (statements) for which respondents expressed their agreement or disagreement. For attitudes that were available for respondents, Likert scale with five levels (range 5 - 9 can be seen as the optimal solution) was applied. All attitudes which were required for this research were formed by the authors.

Table 2. List of attitudes for determining variables - image PMI RTV

\begin{tabular}{|l|}
\hline I have positive associations about PMI RTV (i1) \\
\hline I consider PMI RTV to be a particularly good organization (i2) \\
\hline PMI RTV has a good identity (i3) \\
\hline PMI RTV has a good image (i4) \\
\hline PMI RTV has a good reputation (i5) \\
\hline I have a positive attitude towards PMI RTV (i6) \\
\hline PMI RTV is a bad organization (i7) \\
\hline
\end{tabular}

Table 3. List of attitudes for determining variables - competitiveness PMI RTV

PMI RTV is competitive (k1)

Competitiveness of PMI RTV is higher compared to the competition (k2)

I consider PMI RTV to be more competitive compared to other organizations (k3)

Table 4. List of attitudes for determining variables - intensity of corporate communication of PMI RTV

Corporate communications of PMI RTV are frequent (kk1)

Compared to the competition, PMI RTV has more intense corporate

communications (kk2)

Intensity of the use of corporate communications in PMI RTV is higher

compared to other organizations (kk3)

For the analysis of gathered data, by surveying the external public, multiple regression method was used, which aimed to show that the intensity of corporate communications affects the image of the PMI RTV Vojvodina. The impact of the image 
on competitiveness of PMI RTV Vojvodina was measured by correlation analysis. Gathered data were also analyzed by the additional statistical methods:

Reliability and the validity of the used scale were tested - Cronbach's coefficient - a was calculated and its value if certain attitudes were left out.

Methods of descriptive statistics were used: mean value and frequency distribution.

\section{Research Results}

Table 5. shows the value of Cronbach's coefficient - a for the measurement scale used in this research and processing of obtained data. Cronbach's a coefficient is a measurement for internal consistency of groups of attitudes whose value can range from 0 to 1 . The closer the Cronbach's a coefficient is to 1 , the measurement scale is more reliable. If the coefficient of reliability, including Cronbach's a coefficient is about 0,9 - reliability can be considered to be excellent.

Table 5. The values of Cronbach's coefficient $-a$

\begin{tabular}{|l|l|}
\hline Measurement scale & Cronbach alfa coefficient \\
\hline Image of PMI RTV Vojvodina & 0,92 \\
\hline Competitiveness of PMI RTV Vojvodina & 0,78 \\
\hline Intensity of corporate communications in PMI RTV Vojvodina & 0,87 \\
\hline
\end{tabular}

\section{Source: author's research}

Based on Cronbach's a coefficients, we can conclude that the used measurement scales have a satisfactory level of reliability. Measurement scale for competitiveness of PMI RTV Vojvodina showed the lowest reliability, while the measurement scale for the image of RTV Vojvodina showed the best reliability for which it is even possible to say is excellent. The value of Cronbach's a coefficients of corresponding measurement scales increased, and thus their reliability, leaving out the attitudes that affected the reduction of the reliability of the appropriate measurement scales.

Table 6. The influence of certain attitudes on the Cronbach's a coefficient of the measurement scale for variable - image of PMI RTV Vojvodina

\begin{tabular}{|l|l|}
\hline \multicolumn{2}{|l|}{ Cronbach's a coefficient for the scale is: 0,92} \\
\hline Attitude & Cronbach's a coefficient if an attitude is left out \\
\hline i1 & 0,91 \\
\hline i2 & 0,90 \\
\hline i3 & 0,82 \\
\hline i4 & 0,91 \\
\hline i5 & 0,90 \\
\hline i6 & 0,90 \\
\hline i7 & 0,93 \\
\hline
\end{tabular}

Source: author's research

Table 7. The influence of certain attitudes on the Cronbach's a coefficient of the measurement scale for variable competitiveness of PMI RTV Vojvodina

\begin{tabular}{|l|l|}
\hline \multicolumn{2}{|l|}{ Cronbach's a coefficient for the scale is: 0,78} \\
\hline Attitude & Cronbach's a coefficient if an attitude is left out \\
\hline k1 & 0,80 \\
\hline k2 & 0,67 \\
\hline k3 & 0,60 \\
\hline
\end{tabular}

Source: author's research 
Table 8. The influence of certain attitudes on the Cronbach's a coefficient of the measurement scale for variable - intensity of corporate communications in PMI RTV Vojvodina

\begin{tabular}{|l|l|}
\hline \multicolumn{2}{|l|}{ Cronbach's a coefficient for the scale is: 0,87} \\
\hline Attitude & Cronbach's a coefficient if an attitude is left out \\
\hline kk1 & 0,82 \\
\hline kk2 & 0,81 \\
\hline kk3 & 0,82 \\
\hline
\end{tabular}

Source: author's research

Based on the presented results we can conclude that two attitudes affect the reduction of reliability of the appropriate measurement scale, and those are: attitude (i7) for variable - image of PMI RTV, or (k1) for variable - competitiveness of PMI RTV. By leaving those two out, the value of Cronbach's a coefficient of the appropriate measurement scale was increased, as well as their reliability. Because of that, those attitudes were excluded from further research. The same way the analysis of the validity of used measurement scales was performed by implementation of research analyses of the factors by which convergent and discriminant validity of the measurement scales was parsed. Thus we come to the conclusion that analyzed measurement scales have convergent properties (related claims have high factor loadings on relevant factors) and discriminant validity (related claims have low factor loadings on other factors). Discriminant and convergent validity was tested by exploratory factor analysis and confirmatory factor analysis.

Since the used measurement scales have an acceptable level of reliability and convergent and discriminant validity, the gathered data are analyzed using multiple regression and correlation analysis ${ }^{1}$, all in order to test the defined hypothesis $\mathrm{H} 1$ and $\mathbf{H} 2$. Regression analysis determines the analytical form of relationship between dependent (here we took the image of PMI RTV Vojvodina as a dependent phenomenon), and independent phenomena (the intensity of corporate communications in PMI RTV Vojvodina), describing the connections between them, while correlation analysis establishes a link between the given phenomena - independent and dependent, its shape, strength and direction, without going into what is the cause and what is consequence. The name multiple regression means that there are more independent variables (intensity and competitiveness of PMI RTV Vojvodina in this case) and it uses regression function as the best prediction.

Image 1. Regression model - a schematic representation

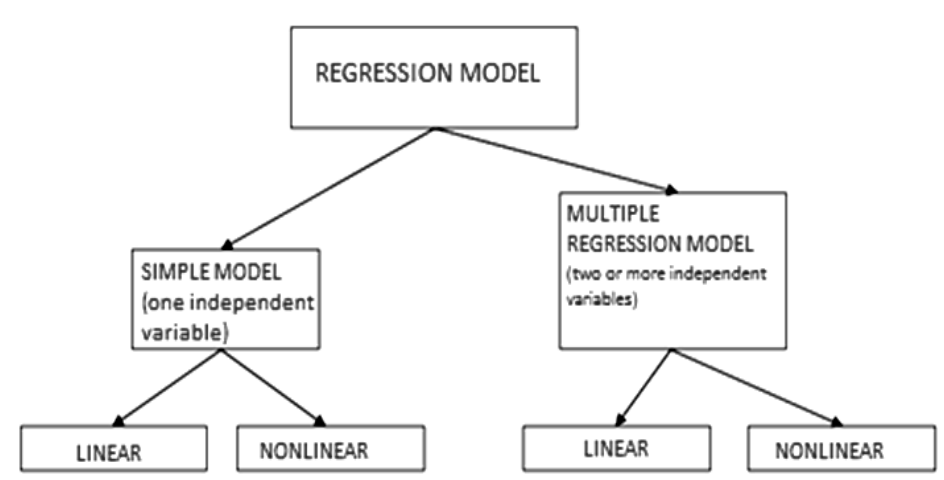

The aim of the testing by multiple regression was to determine whether the independent variable explains a significant part of the variability of the dependent variable, i.e. whether there is a connection between them, also, to determine the strength of the structure of those connections, to predict values of the dependent variables and define the sampling line of the

\footnotetext{
${ }^{1}$ Multiple regression and correlation analysis study the relations between two or more phenomena. The significance of these methods lies in being able to predict the outcome of certain events based on knowledge of other phenomena. The name regression, was introduced by a statistician Sir Frances Galton (1822 -1911) and it means going backwards.
} 
regression with the least possible residuals ${ }^{1}$. In practice standardized residuals are used, which we can get by standardizing residuals, and which have a normal distribution with the middle 0 and deviation 1 .

The first hypothesis $\mathrm{H} 1$ was tested by the use of multiple regression, where the image of PMI RTV Vojvodina is seen as dependent variable, and the intensity of corporate communications in PMI RTV Vojvodina as - independent variable. Mean values of the answers provided by the respondents about the attitudes which belong to those variables were calculated in order to be able to implement multiple regression. For each variable, one summary indicator (mean value) was obtained for each subject, and then those indicators were used as inputs in the implementation of multiple regression.

The assumptions, which the multiple regression model are based on, are similar to those that are valid for simple regression and they state that the form of dependence between all variables is linear, or straight line. This is especially important for the relationship between independent variables and the dependent variable, in this case the image of PMI RTV Vojvodina.

Before explaining the results, their statistical significance must be tested. If $R^{2}, b$ and $\beta$ are not statistically significant, it is concluded that the independent variable - intensity of corporate communication in PMI RTV Vojvodina, has no real connection with the dependent variable - image of PMI RTV Vojvodina, which means that the resulting model has no practical value. If all the regression coefficients are statistically significant, then the coefficient of multiple determination $\mathrm{R}^{2}$ 2 will certainly be significant. This indicates that the purpose of regression in this case is to determine the form of the relationship, namely dependence between the observed phenomena, image of PMI RTV Vojvodina and intensity of corporate communications in PMI RTV Vojvodina. This was achieved by using the appropriate regression model (stochastic model which best describes the quantitative relationship between variations in the observed phenomena in reality through a mathematical formula and a set of appropriate assumptions), which shows the average stacking variation of the tested phenomena. The regression model is not the goal itself, but a means by which we are able to evaluate and predict values of the dependent variable for the desired value of the explanatory variable.

The resulting multiple regression model is statistically significant at the level of $p<0.05$. The coefficient of multiple determination $R^{2}$ is a relative measure and it shows the participation of the explained variability in total (how many variations of variable $Y$ are explained by variable $X$ ), i.e. it represents the quotient of deciding - the ratio of the dispersion of the dependent variable that can be explained by the independent variable. The value of 0.57 represents $57 \%$ of the variability in the dependent variable that can be explained by the independent variable, so the level of connection is strong, i.e. the image of PMI RTV Vojvodina.

Table 9. The results of multiple regression analysis

\begin{tabular}{|l|l|}
\hline Independent variable & Beta coefficient - $\beta$ \\
\hline intensity of corporate communications in PMI RTV Vojvodina & 0,17 \\
\hline
\end{tabular}

${ }^{*}$ statistically significant if $p<0,05$

\section{Source: author's research}

The first hypothesis $\mathrm{H} 1$ : Intensity of corporate communications positively affects the creation of image of PMI RTV Vojvodina, and it is accepted based on the results of the analyses of multiple regression because the following conditions were met.

multiple regression model is statistically significant if $p<0.05$

corresponding coefficient beta - $\beta^{3}$ is statistically significant if $p<0.05$

corresponding beta coefficient $-\beta$ is in the anticipated direction

The second hypothesis H2: Positive image of PMI RTV Vojvodina affects the increase of the competitiveness of PMI RTV Vojvodina. It was tested using correlation analysis between variables - image of PMI RTV and competitiveness of PMI RTV. The correlation coefficient between these two variables is 0.68 so it is statistically significant at the level of $p<0.05$. This

\footnotetext{
${ }^{1}$ Residuals - errors, they should be approximately distributed.

${ }^{2}$ Coefficient of multiple determination (correlation) is used to determine the quality of the prediction of the dependent variable.

${ }^{3}$ corresponding beta coefficient - $\beta$ useful for the interpretation of the relative importance of independent variables
} 
result suggests that the second hypothesis $\mathrm{H} 2$ can be accepted since both defined conditions are met. That is, we can conclude that the positive image of PMI RTV Vojvodina affects the increase of its competitiveness.

\section{Conclusion}

Using existing and creating new channels of communication, an organization creates a safe way for launching messages and plays an active role in building an attitude about the environment towards it - image creation. Image of an organization with corporate identity is a central concept of corporate communication, and as such it has been attracting the attention of a large number of marketing professionals worldwide for many years. By analyzing the available literature, we recognized the causal relationship between corporate communication and image of an organization, as one of the main sources of competitiveness of PMI RTV Vojvodina (Carey, J., 1983, 311-313; Carey J., 1985; Solomon, R.M., Marshall, W.G., Stuart, W.E., 2008, 376). By efficient management of corporate communication, PMI RTV Vojvodina profiles the desired image and creates a suitable position in the minds of the viewers/listeners/portal users and the public, coordinating the tasks that employees do (Jovanović, Živković, Cvetkovski, 2003) (Jovanović, M., Živković, M., Cvetkovski, T., 2003).

Corporate communication is directed towards the organization as a whole and towards the importance of its image (Dolphin, 2000). Mastering communication skills itself, does not lead to corporate identity, image or reputation of the company. Managerial competence is necessary so that the position and reputation of the company can be analyzed, corporate image/identity (corporate values, messages) determined, communication plan designed and developed, and finally, the results can be evaluated after the implementation of the plan. This is where the strategic management comes into play, and it is assumed that managers must be able to monitor and critically understand the actions taken, as well as to create communication programs which are appropriate for corporate goals. The organization needs to understand, from a strategic point of view, which is the most effective way of functioning of corporate communications, and how they can be used to achieve corporate objectives, to organize them, and decide what means should be used to complete their potential. Corporate communications also have an important role in decision-making and overall corporate strategy. They are integrated into the corporate goals, mostly with long-term implications. From the above, we can conclude that the corporate communication is: management function that requires from the communicator a complete understanding of communication and integration of communication strategies with corporate strategy and objectives (strategically planned series of activities which emegres from the general corporate strategy); According to Cornelissen (Cornelissen J., 2004), a version of the definition of the relations between corporate communications and image might sound like this: Corporate communication is a management function that offers the effective coordination of all means of communication, with the ultimate goal of establishing and maintaining the desired reputation i.e. the image of the group of stakeholders whom the organization depends on.

In order to test the hypotheses, a comprehensive research was conducted. Both hypotheses were accepted by the analysis of the obtained data, and the implications are possible benefits for PMI RTV Vojvodina i.e. the possibilities for strategic and long-term image management as well as its competitiveness by means of intensive, integrated and quality of corporate communication activities in the market.

The first implication indicates the need for forecasting further growth of the intensity of corporate communications in PMI RTV Vojvodina with absolute imperative - the integration of complete corporate communication activities of the organization, with the purpose of quality control over their own image, because there is reasonable doubt that all forms of corporate communication are not equally used. Changes in behavior and expectations of viewers/listeners/portal users, as well as the communication revolution in PMI RTV Vojvodina set imperative of constant monitoring of modern communication trends and adjustment to their own corporate communication activities in accordance with the current communication moment.

The second implication is based on recognition of the important role of the image of PMI RTV Vojvodina, whose quality in the current economic conditions and in conditions of high market competitiveness directly affects the competitiveness of the organization i.e. the viewership/listenership/citations. Corporate communication has a strategically important role in the process of quality image management in PMI RTV Vojvodina.

The research results show that the achieved level of image quality of PMI RTV Vojvodina is directly connected and dependent on the success of the organization to properly organize, implement and integrate their own corporate communications activities in practice, and to apply them with appropriate intensity. The higher the level of intensity of total corporate communication activities of the organization, better it is able to manage its own image. The research results also 
show the existence of a direct link between the achieved level of image quality of PMI RTV Vojvodina, based on integrated and intensive corporate communication activities and its competitiveness. We can conclude that the competitiveness of PMI RTV Vojvodina is equal to its image based on integrity, and intensity of corporate communication activities at the level of marketing, organizational and managerial communication. The competitiveness of the organization is deeply rooted in the concept of corporate communications, i.e. it is under the direct influence of the image of PMI RTV Vojvodina, based on intensive and integrated corporate communication activities. This is how the image of PMI RTV Vojvodina becomes a direct source of competitive advantage of the organization in modern market conditions, highlighting the strategic importance of corporate communications.

\section{Literature}

[1] Balmer, J.M.T. \& van Riel, C.B.M. (1997). Corporate Identity: The Concept, Its Measurement and Management. European Journal of Marketing , Vol.31, No.5/6, 340-355.

[2] Barich, H. \& Kotler, P. (1991.). "A Framework for Managing Image Management". Sloan Management Review , Vol.32, No.2, 94.

[3] Burke, T. (1998.). Risks and reputations: The economics of transaction costs. Corporate Communications, Vol.3, No.1, 5-10.

[4] Capoozzi, L. (2005.). Corporate Reutation: Our Role in Sustaining and Building a Valuable Asset. Journal of Advertising Reserach, Vol.45, No.3, 209-293.

[5] Carey, J. (1983). "The Origins of the Radical Discourse on Cultural Studies in the United States". Journal of Communication, $33(3)$, , 311-313.

[6] Carey, J. W. (1985). "Overcoming Resistance to Cultural Studies". Communication as Culture .

[7] Cornelissen, J. (2004). Corporate Communcations - Theory and Practice. Sage Publications.

[8] Cornelissen, P. (2003). Change, Continuity and Progress: The Concept of Integreated Marketing Communications and Marketing Communications Practice. Journal of Strategic Marketing , Vol.11, No.4, 217-234.

[9] Dentchev, A.N. \& Heene A. (2004.). Managing the Reputation of Restructuring Corporations: Sending the Right Signal to the Right Stakeholder. Journal of Public Affairs, Vol.4, No.1, 56-72.

[10] Dolphin, R. (2000). The Fundamentals of Corporate. Butterworth-Heinemann.

[11] Donaldson, T. \& Preston, L.E. (1995.). The Stakeholder Theory of the Corporation Concepts, Evidence and Implications. Academy of Management Review, Vol.20, No.1, 65-91.

[12] Dowling, G. (2004.). Journalists' Evaluations of Corporate Reputations. Corporate Reputation Review , Vol.7, No.2, $196-205$.

[13] Flatt S. J. \& Kowalczyk S. J. (2008.). Creating Competitive Advantage Through Intangible Assets:The Direct And Indirect Effects Of Corporate Culture And Reputation. Advances in Competitiveness, Vol.16, No.1, 13-30.

[14] Forman J. \& Argenti P.A. (2005.). How Corporate Communication Influences Strategy Implementation, Reputation and the Corporate Brand: An Exploratory Qualitative Study. Corporate Reputation Review, Vol.8, No.3, 245-264.

[15] Freeman, R. E. \& McVea, J. (2001.). A Stakeholder Astrroach to Strategic Management. Darden Business School Working Paper, No. 01-02.

[16] Grey, E. \& Smeltzer, L. (1985.). SMR Forum: Corporate Image - An Integral Part of Strategy. Sloan Management Review (Summer), 73-78.

[17] Hawabhay B.B., Abratt R. \& Peters M. (2009.). The Role of Corporate Communications in Developing a Corporate Brand Image and Reputation in Mauritius. Corporate Reputation Review, Vol. 12, No.1, 3-20.

[18] Jovanović, M., Živković, M. \& Cvetkovski, T. (2003.). Organizaciono ponašanje. Beograd: Megatrend univezitet primenjenih nauka.

[19] Jovanović, M., Živković, M., Cvetkovski, T. (2003). Organizaciono ponašanje. Megatrend univerzitet.

[20] Kotler, P. (1997.). Marketing Management: Analysis, Planning, Implementation and Control (9th Edition ed.). London: Prentice Hall International.

[21] Mendel, T. (1999, February 5). Public Service Broadcasting: International Standards. Retrieved November 10, 2015. from http://portal.unesco.org/ci/en/ev.php-URL_ID=1525\&URL_DO=DO_TOPIC\&URL_SECTION=201.html

[22] RS, M. k. (2006, April 20). Zakon o radiodifuziji. Retrieved January 20, 2014 from http://www.pks.rs/SADRZAJ/Files/Kreativna/5524-zakon_o_radiodifuziji.pdf

[23] RS, N. S. (2014, August 14). Zakon o Javnim medijskim servisima. Retrieved August 20,2014 from http://www.parlament.gov.rs/upload/archive/files/cir/pdf/zakoni/2014/2513-14.pdf

[24] RTV, J. (2013, July 13). Strategija razvoja RUV RTV 2013-2017. Retrieved August 25, 2013 from http://static.rtv.rs/pdf/2013/10/29/strategija-razvoja-ruv-rtv-2013-2017-pdf.pdf

[25] Solomon, R. M., Marshall, W.G., Stuart, W.E. (2008). Marketing, Real People, Real Choices. Pearson, Prentice Hall.

[26] van Riel, C. (1995). Principleas of Corporate Communication. London: Prentice Hall.

[27] Veljanovski, R. (2005). Javni RTV servisi u službi građana. Beograd: Clio.

[28] Verčić, D., Zavrl, F., Rijavec, P., Ognjanov, G. \& Brbaklić, A. (2004.). Odnosi sa medijima. Beograd: Medija Centar i Pristop.

[29] Worchester, R. (1997). Managing the Image of Bank: The Glue That Binds. International Journal of Bank Management , Vol.15, No.5, 146. 